\title{
Senior Management Team Performance Evaluation Research based on Human Capital

\author{
Shao Xiaoyun
}

Jiangxi Normal University, Jiangxi, Jiujiang, China

xiaoyu7@163.com

Keywords: human capital value; human capital property right; senior management team; the performance evaluation

\begin{abstract}
As an enterprise strategic control layer, the senior management team is the core and the soul of the enterprise, which bears the mission of enterprise strategy and decides the survival and future development of enterprises, besides, it enjoys high value of human capital. Building evaluation system of senior management team from three dimensions-individual, team and organization, decomposing each dimension and refining quantifiable, easy to measure and inspect indicators. At the same time using the survey results to support the above qualitative analysis. Therefore, we could get the senior management team performance from the individual, team, and organization dimensions. Among which, personal dimension is the foundation providing the basic source and basis for the team and the organization dimensions; team dimension is the core integrating the personal ability, performance, etc, besides, in the form of team operation, it forms the coordination effect creating more cumulative value; the organization dimension provides the basic environment and institutional guarantee for individual and team dimension, and create conditions to improve the performance of senior management team as a whole.
\end{abstract}

\section{Introduction}

In today's society, the human resources play an important role for the survival and development of enterprises. To effectively solve the problems of value of human capital, distribution of human capital income, information disclosure and enterprise overall benefit etc, it is necessary to have a discuss about its roots - human capital value and property rights defining method, thus to realize the assessment of existing human resources and potential capability, the distribution of human capital involved in enterprise residual income, and to enhance the enthusiasm of the members of the senior management team and to promote the development of relevant theory and practice of human capital. Thus, based on the perspective of human capital to build reasonable and effective performance evaluation system of senior management team is helpful to improve the competitive advantage of enterprises, produce strategic guidance employee behavior, finally improve the business performance.

\section{Model Building, Weight Determination and One-Time Inspection}

This paper, based on the multi-level grey evaluation method from individual, team and organization-three dimensions, builds evaluation system for senior management team and conducts performance evaluation. The grey system theory takes changing grey amount of the random process within a certain perios of time, a certain range as grey system. Top management team performance can be regarded as a grey system, on the one hand, because its influencial factors are numerous and complex, on the other hand, the system has the characteristic of incomplete information.

Assume that $\mathrm{P}$ is evaluation target layer, namely top management team performance, and $\mathrm{K}, \mathrm{M}$, $\mathrm{N}$, in turn, symbolize individual, team, and organization-three evaluation dimensions, $\mathrm{V}$ symbolizes criterion layer, and $\mathrm{W}$ for evaluation index layer, thus, each layer has its subrunch belonging to the group:

$\mathrm{P}=(\mathrm{K}, \mathrm{M}), \mathrm{K}_{1}=\left(\mathrm{V}_{1}, \mathrm{~V}_{2}, \mathrm{~V}_{3}\right), \mathrm{M}_{1}=\left(\mathrm{V}_{4}, \mathrm{~V}_{5}, \mathrm{~V}_{6}, \mathrm{~V}_{7}, \mathrm{~V}_{8}, \mathrm{~V}_{9}\right), \mathrm{N}_{1}=\left(\mathrm{W}_{101}, \mathrm{~W}_{102}, \mathrm{~W}_{103}\right.$, 
$\left.W_{104}, W_{105}\right), B_{1 j}=\left(W_{11}, W_{12}, W_{13}\right), B_{2 j}=\left(W_{21}, W_{22}, W_{23}, W_{24}, W_{25}, W_{26}\right), B_{3 j}=\left(W_{31}, W_{31}\right.$, $\left.W_{33}, W_{34}\right), B_{4 j}=\left(W_{41}, W_{41}, W_{43}, W_{44}\right), B_{5 j}=\left(W_{51}, W_{51}\right), B_{6 j}=\left(W_{61}, W_{62}\right), B_{8 j}=\left(W_{81}, W_{82}\right.$, $\left.\mathrm{W}_{83}\right), \mathrm{B}_{9 \mathrm{j}}=\left(\mathrm{W}_{91}, \mathrm{~W}_{92}, \mathrm{~W}_{93}\right)$.

Weight Determination. First of all, using Analytical Hierarchy Process Method (AHP) to determine the weight of each evaluation index, and the specific steps are as follows:

1) Constructing judgment matrix and calculating the value of each column: Comparing judgment matrix in twos. Here, taking the five defining ways of human capital of organization dimension mode as an example, and taking the five unified methods as five indicators of organizational dimension, under the condition that there is no clarification between monetary and non-monetary forms. While doing comparison, there must be certain reference standard and scale, specifics can be seen in table 1.

Table 1 Using AHP to compare the comparative measures of each index’s importance

\begin{tabular}{|l|l|}
\hline scale & meaning \\
\hline 1 & the former is as important as the former \\
\hline 3 & the former is more important than the latter \\
\hline 5 & the former is far more important than the latter \\
\hline 7 & $\begin{array}{l}\text { the former is sure more important than the latter } \\
\text { the former is undoubtedly more important than the } \\
\text { latter }\end{array}$ \\
\hline 9 & $\begin{array}{l}\text { intermediate value between the above adjacent } \\
\text { judgments }\end{array}$ \\
\hline $2,4,6,8$ & $\begin{array}{l}\text { the ratio of the latter to the former is the reciprocal } \\
\text { the ratio of the former to the latter }\end{array}$ \\
\hline reciprocal & \begin{tabular}{l} 
and \\
\hline 0
\end{tabular}
\end{tabular}

Referring to the scale, comparing the five indicators of human capital profit in twos, and the expert team participate in the process of concrete index comparison. Among which, the expert team is composed of 25 high-tech enterprises and 37 of the traditional senior management team members. Collecting the opinions of experts and doing statistical analysis we could get the following judgment matrix:

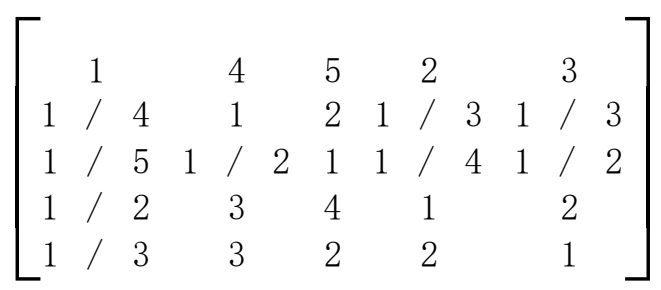

2) Each item in the matrix divided by the sum of the line it is, the following matrix could be got:

$\left[\begin{array}{lllll}0.438 & 0.380 & 0.333 & 0.490 & 0.439 \\ 0.110 & 0.095 & 0.133 & 0.082 & 0.049 \\ 0.088 & 0.048 & 0.067 & 0.061 & 0.073 \\ 0.219 & 0.286 & 0.267 & 0.245 & 0.293 \\ 0.146 & 0.190 & 0.200 & 0.122 & 0.146\end{array}\right]$

3) Calculate the average in per line, and determine the priority level of each dimension, see in table 2:

\begin{tabular}{|l|l|l|l|l|l|}
\hline Index layer & $\begin{array}{l}\text { annual } \\
\text { salary } \\
\text { system }\end{array}$ & $\begin{array}{l}\text { Equity } \\
\text { incentive }\end{array}$ & $\begin{array}{l}\text { Managemen } \\
\text { t of shares }\end{array}$ & $\begin{array}{l}\text { Right of } \\
\text { control }\end{array}$ & $\begin{array}{l}\text { Promotion, on-the-job } \\
\text { consumption, etc }\end{array}$ \\
\hline $\begin{array}{l}\text { Weight } \\
\text { determination }\end{array}$ & 0.416 & 0.094 & 0.067 & 0.262 & 0.161 \\
\hline
\end{tabular}


Consistency Check. When using the Analytic Hierarchy Process Method (AHP), it could be difficult to achieve exact consistence. Therefore, the AHP provides a method for consistency check. If the consistency degree can not meet the requirements, you must review and modify comparison results in twos. Concrete method is to calculate the consistency ratio, if the ratio is greater than 0.10 , which suggests that there exists judgments inconsistent in the two comparisons; If the ratio is less than or equal to 0.10 , the pair comparison results are reasonable, then we can take the next calculation step.1) Take every item in the first column in the pair matrix to multiply the first indicator's priority level, and take every item in the second column to multiply the second indicator's priority level, like this to calculate the sum of all lines, the vecor's weighted value could be obtained:

$$
\begin{gathered}
0.416\left[\begin{array}{l}
1 \\
1 / 4 \\
1 / 5 \\
1 / 2 \\
1 / 3
\end{array}\right]+0.094\left[\begin{array}{l}
4 \\
1 \\
1 / 2 \\
3 \\
2
\end{array}\right]+0.067\left[\begin{array}{l}
5 \\
2 \\
1 \\
4 \\
3
\end{array}\right]+0.262\left[\begin{array}{l}
2 \\
1 / 3 \\
1 / 4 \\
1 \\
1 / 2
\end{array}\right]+0.161\left[\begin{array}{l}
3 \\
1 / 3 \\
1 / 2 \\
2 \\
1
\end{array}\right] \\
=\left[\begin{array}{l}
0.416 \\
0.104 \\
0.083 \\
0.208 \\
0.139
\end{array}\right]+\left[\begin{array}{l}
0.376 \\
0.094 \\
0.047 \\
0.282 \\
0.188
\end{array}\right]+\left[\begin{array}{l}
0.335 \\
0.134 \\
0.067 \\
0.268 \\
0.201
\end{array}\right]+\left[\begin{array}{l}
0.524 \\
0.087 \\
0.066 \\
0.262 \\
0.131
\end{array}\right]+\left[\begin{array}{l}
0.483 \\
0.054 \\
0.081 \\
0.322 \\
0.161
\end{array}\right]=\left[\begin{array}{l}
2.134 \\
0.473 \\
0.344 \\
1.342 \\
0.820
\end{array}\right]
\end{gathered}
$$

2) Dividing the vecor's weighted value by the corresponding index's priority level, the results are as follows:

$$
\begin{aligned}
& W_{101} ; \frac{2.134}{0.416}=5.130 ; W_{102}: \frac{0.473}{0.094}=5.032 ; W_{103}: \frac{0.344}{0.067}=5.134 ; \\
& W_{104}: \frac{1.342}{0.262}=5.122 ; W_{105}: \frac{0.820}{0.161}=5.093
\end{aligned}
$$

3) calculate the above to get the average number- $\lambda_{\max }$ :

4) calculate the consistency ratio CI, CR:

$$
\begin{aligned}
& \mathrm{CI}=\frac{\lambda \max -\mathrm{n}}{\mathrm{n}-1}=\frac{5.1022-5}{5-1}=0.02555 \\
& \mathrm{CR}=\frac{\mathrm{CI}}{\mathrm{RI}}=\frac{0.02555}{1.12}=0.023
\end{aligned}
$$

Among them, is the RI is the randomly generated through pairwise comparison matrix is then generated. The RI value depends on the number in the comparison matrix, which is shown in the following table 3 :

Table 3 RI reference value

\begin{tabular}{|l|l|l|l|l|l|l|}
\hline $\mathrm{n}$ & 3 & 4 & 5 & 6 & 7 & 8 \\
$\mathrm{RI}$ & 0.58 & 0.90 & 1.12 & 1.24 & 1.32 & 1.41 \\
\hline
\end{tabular}

As mentioned above, the consistency ratio is 0.023 , less than 0.10 , therefore it is acceptable. So, consistency degree between the pair comparisons meet the requirements, and the obtained weight determination could be taken as weight coefficient of the five indicators.

Using the same method, other each index's weight coefficients could be obtained, and one-time ratio is less than or equal to 0.10 , the consistency degree of the pair comparison is in conformity with the requirements, so the weight coefficient are effective. The results are shown in table 3. 


\section{Top Management Team Performance Evaluation System.}

Table 4 Top Management Team Performance Evaluation System

\begin{tabular}{|c|c|c|c|c|}
\hline $\begin{array}{c}\text { The target } \\
\text { layer }\end{array}$ & $\begin{array}{c}\text { dimension } \\
\mathrm{s}\end{array}$ & $\begin{array}{l}\text { criterion } \\
\text { layer (V) }\end{array}$ & index layer（W） & $\begin{array}{c}\text { Weight } \\
\text { determination }\end{array}$ \\
\hline \multirow{33}{*}{$\begin{array}{c}\text { top } \\
\text { management } \\
\text { team } \\
\text { performance } \\
\text { evaluation } \\
\text { (P) }\end{array}$} & \multirow{13}{*}{$\begin{array}{c}\text { Personal } \\
\text { dimensi } \\
\text { on } \\
(\mathrm{K})\end{array}$} & \multirow{3}{*}{$\begin{array}{l}\text { contribution } \\
\left(\mathrm{V}_{1}\right)\end{array}$} & Work achievement number (W11) & 0.296 \\
\hline & & & work efficiency（W12） & 0.423 \\
\hline & & & $\begin{array}{l}\text { Cultivated number of the } \\
\text { subordinates ( W13) }\end{array}$ & 0.281 \\
\hline & & \multirow{6}{*}{$\begin{array}{l}\text { ability } \\
\text { ( V2) }\end{array}$} & $\begin{array}{l}\text { The number of newly developed } \\
\text { customer (W21) }\end{array}$ & 0.146 \\
\hline & & & $\begin{array}{l}\text { Turnover rate of key members } \\
\text { (W22) }\end{array}$ & 0.148 \\
\hline & & & Decision-making yields（W23） & 0.202 \\
\hline & & & Innovation decision ratio (W24) & 0.161 \\
\hline & & & Risk treatment results（W25） & 0.150 \\
\hline & & & $\begin{array}{l}\text { Office system operation level } \\
\text { (W26) }\end{array}$ & 0.193 \\
\hline & & \multirow{4}{*}{$\begin{array}{l}\text { Basic } \\
\text { quality } \\
\text { ( V3) }\end{array}$} & Diploma level（W31） & 0.250 \\
\hline & & & $\begin{array}{l}\text { The accumulative working years } \\
\text { (W32) }\end{array}$ & 0.261 \\
\hline & & & health condition (W33) & 0.238 \\
\hline & & & $\begin{array}{l}\text { psychological enduring capacity } \\
\text { (W34) }\end{array}$ & 0.251 \\
\hline & \multirow{15}{*}{$\begin{array}{c}\text { Group } \\
\text { dimensi } \\
\text { on } \\
(\mathrm{M})\end{array}$} & \multirow{4}{*}{$\begin{array}{c}\text { Team } \\
\text { structure } \\
\text { (V4) }\end{array}$} & Group size (W41) & 0.254 \\
\hline & & & $\begin{array}{c}\text { reasonable degree of team work } \\
\text { mechanism (W42) }\end{array}$ & 0.302 \\
\hline & & & $\begin{array}{l}\text { Complementary degree of skill } \\
\text { and profession (W43) }\end{array}$ & 0.265 \\
\hline & & & $\begin{array}{l}\text { Completion degree of democracy } \\
\text { and supervision system ( W44) }\end{array}$ & 0.179 \\
\hline & & \multirow{2}{*}{$\begin{array}{l}\text { communica } \\
\text { tion and } \\
\text { cooperation } \\
\text { ( V5) }\end{array}$} & $\begin{array}{l}\text { Team communication times and } \\
\text { frequency (W51) }\end{array}$ & 0.580 \\
\hline & & & $\begin{array}{c}\text { perfect degree of communication } \\
\text { mechanism (W52) }\end{array}$ & 0.420 \\
\hline & & \multirow{2}{*}{$\begin{array}{l}\text { shared } \\
\text { vision } \\
\text { ( V6) }\end{array}$} & $\begin{array}{l}\text { Team strategy and vision clarity } \\
\text { (W61) }\end{array}$ & 0.50 \\
\hline & & & $\begin{array}{l}\text { Team strategy and vision } \\
\text { recognition degree }(\mathrm{W} 62)\end{array}$ & 0.50 \\
\hline & & $\begin{array}{c}\text { Shared } \\
\text { knowledge } \\
\text { (V7) }\end{array}$ & $\begin{array}{l}\text { Perfection degree of information } \\
\text { sharing network platform ( W71) }\end{array}$ & 1.00 \\
\hline & & \multirow{3}{*}{$\begin{array}{c}\text { Conflict } \\
\text { manageme } \\
\mathrm{nt} \\
\left(\mathrm{V}_{8}\right)\end{array}$} & Team member turnover ( W81) & 0.281 \\
\hline & & & $\begin{array}{l}\text { Conflicts number of and } \\
\text { frequency (W82) }\end{array}$ & 0.267 \\
\hline & & & $\begin{array}{l}\text { Reasonable degree of conflict } \\
\text { resolution mechanism ( W83) }\end{array}$ & 0.452 \\
\hline & & \multirow{3}{*}{$\begin{array}{c}\text { achievemen } \\
\mathrm{t} \\
\left(\mathrm{V}_{9}\right)\end{array}$} & team achievement number (W91) & 0.260 \\
\hline & & & $\begin{array}{l}\text { time span and frequency of results } \\
\text { (W92) }\end{array}$ & 0.280 \\
\hline & & & Team work yields ratio（W93） & 0.460 \\
\hline & \multirow{5}{*}{$\begin{array}{l}\text { Organiza } \\
\text { tion } \\
\text { dimensi } \\
\text { on } \\
(\mathrm{N})\end{array}$} & \multirow{5}{*}{$\begin{array}{l}\text { Physical } \\
\text { objects, } \\
\text { money, } \\
\text { non-moneta } \\
\text { ry form } \\
\text { ( V10) }\end{array}$} & annual salary system (W101) & 0.416 \\
\hline & & & Equity incentive (W102) & 0.094 \\
\hline & & & Management of shares (W103) & 0.067 \\
\hline & & & Right of control（W104） & 0.262 \\
\hline & & & $\begin{array}{c}\text { rank-rise, promotion and } \\
\text { on-the-job consumption (W105) }\end{array}$ & 0.161 \\
\hline
\end{tabular}


Among them, the organizational dimension mainly through different means of enterprise human capital achievement to inspect the definition degree of the property right of the enterprise's human capital and the motivation constituted agianst the senior management team members, thus to futhur evaluate the top management team performance. Human capital property right, which is the human capital owners' right of decision-making power and behavior choice and also is the responsibility based on this kind of power. The responsibility here refers to be responsible to the loss and gains of one's own behavior decision-making and behavior options .

The right of managing human capital is to solve human capital owners' choice problem, while the responsibility is to solve the dynamic level problem of efforts. The right of managing human capital could be called behavioral space or behavior domain, and the greater the human capital owner's behavior space, the greater the degree of the human capital owners' ability could be, namely there are more opportunities for them to show their ability. This could be shown in the chart below:

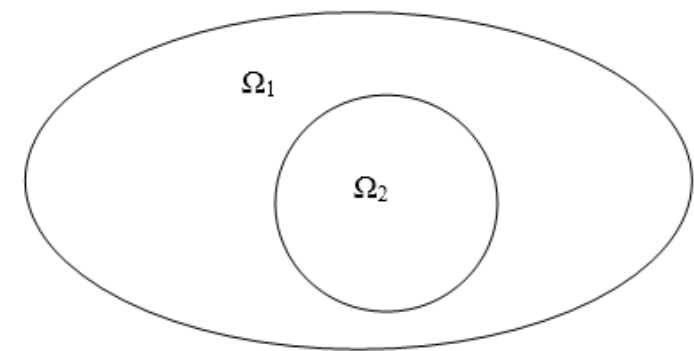

Figure 1 The right of managing human capital diagram

\section{Conclusion}

Based on the perspective of human capital, this article mainly analyzes the organization's human capital property right definition, as well as the senior management team members' motivation, influence on attitude, effort and performance, etc, and the potential value of human capital. Among which, personal dimension is the foundation providing basic source and basis for group and organization dimensions; Team dimension is the core inspection dimension of senior management team performance. Integrating personal ability, performance, etc, and through the team operation form to form the coordination effect of the team, thus to create more cumulative value; The organization dimension provides basic environment and institutional guarantee for individual and team dimensions, besides, it creates conditions to improve the performance of senior management team as a whole.

\section{References}

[1]Wu Bin, Huang Mingfeng. Enterprise Performance, Executive Human Capital Characteristics and Control Configuration_-Based on the Experience of our Country's Small and Medium-Sized Enterprise [J]. Chinese Soft Science, 2011, (4) : 161-174.

[2] Zhao Shijun, Ge Yuhui, Chen Yueming. Model Study Based on the Implicit Value of Human Capital Factor, the Senior Management Team and Team Performance Relationship[J]. Science and Technology Progress and Countermeasures, 2011, (16) : 135-137.

[3] Wu Bin, Huang Mingfeng. Human Capital Characteristics of Venture Capital Enterprise Executives and Business Performance-Empirical Data from Shenzhen's Small and Medium-Sized Plates [J]. Journal of Shanxi University of Finance and Economics, 2010, (03) : 88-94.

[4] Liu Pingping. Enterprise Risk Control of Configuration Study[J]. Journal of Northwestern Polytechnical University (Social Science Edition), 2006 (02) 135-137.. 
[5] Wu Bin, Huang Mingfeng. Human Capital Characteristics of Venture Capital Enterprise Executives and Business Performance-Empirical Data from Shenzhen's Small and Medium-Sized Plates [J]. Journal of Shanxi University of Finance and Economics, 2010, (03) 135-137.

[6] Jiang Ling. Top Management Team Characteristics' Influence on Enterprise Performance_-Based on the Empirical Analysis of Listed Companies in China [J]. Journal of Zhongyuan Institute of Technology. 2008 (04) 135-137.

[7] Jia Dan. Theory of Different Industries under the Background of TMT Heterogeneity Effects on Enterprise Performance[J]. Business Times. 2008 (18) 135-137. 